\title{
Robust Survival of Isolated Bovine Adrenal Chromaffin Cells following Intrastriatal Transplantation: A Novel Hypothesis of Adrenal Graft Viability
}

\author{
Sherry B. Schueler, ${ }^{1}$ John D. Ortega, ${ }^{1}$ Jacqueline Sagen, ${ }^{1}$ and Jeffrey H. Kordower ${ }^{2}$ \\ 'Department of Anatomy and Cell Biology, University of Illinois School of Medicine and ${ }^{2}$ Department of Neurological \\ Sciences, Rush Presbyterian-St. Luke's Medical Center, Chicago, Illinois 60612
}

Previous investigations have demonstrated that adrenal chromaffin cells survive poorly when grafted into the striatum of rodents, nonhuman primates, and patients with Parkinson's disease. This poor survival has been attributed to the low levels of endogenous NGF within the striatum. However, chromaffin cells isolated from the nonchromaffin constituents of the adrenal medulla (fibroblasts and endothelial cells) have recently been demonstrated to survive grafting into a number of CNS sites. The present study determined whether nonchromaffin constituents of the adrenal medulla may be responsible for poor graft survival. We compared the survival of intrastriatally grafted isolated bovine chromaffin cells with that observed following implantation of either perfused adrenal medullary suspensions containing all adrenal medullary cell types or isolated chromaffin cells that were then reseeded with autologous fibroblasts and endothelial cells. Implants of perfused adrenal medullary cells survived poorly and most graft sites were infiltrated with macrophages. The chromaffin cells in this group that did survive appeared to be in the process of degeneration. In contrast, large numbers of isolated chromaffin cells survived for up to 2 months following transplantation. These cells maintained their endocrihe phenotype and stained for all enzymatic markers of catecholamine synthesis as well as chromogranin A. Morphologically, these cells resembled chromatfin cells seen in situ and the perigraft region was essentially devoid of macrophages. When isolated chromaffin cells were reseeded with autologous fibroblasts and endothelial cells, the implants degenerated and few, if any, surviving chromaffin cells were observed. Interestingly, these latter grafts induced a host-derived sprouting response of tyrosine hydroxylase-immunoreactive fibers. These data demonstrate that large numbers of adrenal chromaffin cells can survive intrastriatal implantation in the absence of exposure to exogenous NGF. Rather, the nonchromaffin cells of the adrenal medulla (fibroblasts and endothelial cells) appear to com-

\footnotetext{
Received Dec. 8, 1992; revised Mar. 18, 1993; accepted May 3, 1993.

We thank Dr. Elliott J. Mufson for critically reading the manuscript. We also thank Kathy Gorny for expert technical assistance and Rosanne Brady for photographic assistance. This work was supported by the United Parkinson's Foundation, the Parkinson's Disease Foundation, and NIH Grants NS25054 and NS28931.

Correspondence should be addressed to Dr. Jeffrey H. Kordower, Department of Neurological Sciences, Rush Presbyterian Medical Center, 2242 West Harrison Street, Chicago, IL 60612.

Copyright (C) 1993 Society for Neuroscience $0270-6474 / 93 / 134496-15 \$ 05.00 / 0$
}

promise the viability of grafted chromaffin cells. Once they are eliminated from the graft, robust survival of chromaffin cells occurs. If clinical trials employing adrenal medullary grafts are still to be considered for the treatment of Parkinson's disease, isolation of the chromaffin cells should be considered to enhance graft viability.

[Key words: adrenal medulla, chromaffin cells, grafts, Parkinson's disease, striatum, rats]

Parkinson's disease is characterized by the degeneration of dopaminergic neurons in the substantia nigra pars compacta resulting in a dopamine insufficiency within the striatum. Studies carried out in rodent and nonhuman primate models of Parkinson's disease have attempted to replace lost dopamine through the intracerebral implantation of dopamine-secreting cells. In this regard, a number of different donor tissues have been employed. For instance, transplants of fetal substantia nigra into the caudate and putamen have been extensively evaluated. These cells survive, reinnervate the host striatum, release dopamine, are electrophysiologically active, and completely reverse the abnormal motor sequelae resulting from 6-hydroxydopamine and $n$-methyl-4-phenyl-1,2,3,6-tetrahydropyridine (MPTP) lesions of the substantia nigra in rodents (e.g., Björklund and Stenevi, 1979a,b; Perlow et al., 1979; Björklund et al., 1980, 1981; Freed et al., 1980; Dunnett et al., 1981; Wictorin et al., 1992) and nonhuman primates (Sladek et al., 1986, 1988; Bakay et al., 1987; Fine et al., 1988; Redmond et al., 1988; Bankiewicz et al., 1990a,b), respectively (see review by Yurek and Sladek, 1990).

The social, political, and ethical complications entangling the use of fetal tissues led investigators to evaluate paraneural sources of dopamine-secreting cells for implantation. These include cells of the carotid body (Bing et al., 1988), and tumor cells such as the pheochromocytoma line (Hefti et al., 1985; Jaeger, 1985, 1987; Allen, 1988). The most utilized paraneural source of catecholamine cells is the chromaffin cells of the adrenal medulla, which synthesize dopamine as a precursor for norepinephrine and epinephrine. When dissected from the surrounding adrenal cortex, adrenal chromaffin cells shift their catecholamine synthesis toward a more dopaminergic phenotype although they still produce more norepinephrine and epinephrine than dopamine. Pioneering studies by Freed and coworkers (e.g., Freed et al., 1981, 1983, 1985, 1986; see review by Freed et al., 1990) demonstrated that adrenal medullary transplants survive within the lateral ventricle, secrete catecholamines, and partially reverse drug-induced motor deficits following unilateral nigrostri- 
atal lesions. Recent investigation suggests that the functional recovery seen following adrenal medullary transplants may be due, in part, to a local breakdown of the blood-brain barrier (see review by Freed et al., 1990). While initial clinical trials employing adrenal medullary implants were for the most part (Backlund et al., 1985; Lindvall et al., 1987), Madrazo and coworkers reported that intracaudate implantation of adrenal medulla resulted in a dramatic amelioration of parkinsonian symptoms (Madrazo et al., 1987a,b). These reports resulted in a flurry of clinical trials that were unable to replicate these dramatic findings (Penn et al., 1988; Allen et al., 1989; Goetz et al., 1989; Kelly et al., 1989; Ahlskog et al., 1990; Apuzzo et al., 1990; Lopez-Lozano et al., 1990; Olanow et al., 1990).

Clinical adrenal autograft trials continued to be carried out despite an emerging consensus that adrenal medullary cells survive poorly when grafted into brain parenchyma. Indeed, studies carried out in rats (Strömberg et al., 1984; Herrera-Marschitz et al., 1984; Freed et al., 1986; Bing et al., 1990) and nonhuman primates (Morihisa et al., 1984; Bankiewicz et al., 1988, 1990a,b; Hansen et al., 1988, 1989, 1990; Plunkett et al., 1990) consistently demonstrated that chromaffin cells fail to survive in significant numbers when grafted directly into the striatum. Some studies failed to demonstrate the survival of histochemically identified grafted chromaffin cells for more than $400 \mathrm{~min}$ (Herrera-Marschitz et al., 1984; Strömberg et al., 1984), and macrophages and inflammatory cells appear to be the principal cell types within the graft region. Recent postmortem analyses of patients receiving chromaffin cell implants confirmed findings reported in nonhumans (Frank et al., 1988; Hurtig et al., 1989; Jankovick et al., 1989; Peterson et al., 1989; Hirsch et al., 1990; Waters et al., 1990), with only onc study dcmonstrating the survival of a few tyrosine hydroxylase (TH)-immunoreactive cells (Kordower et al., 1991).

The poor survival of intrastriatally grafted adrenal cells has been attributed to the low levels of endogenous NGF within the striatum (see reviews by Freed et al., 1990; Kordower et al., 1990a; 1992). It has been known for some time that adrenal chromaflin cells are exquisitely sensitive to the trophic and tropic influences of NGF in vitro (e.g., Unsicker et al., 1978; Notter et al., 1989). Strömberg et al. (1985) initially demonstrated that treatment of chromaffin cells with NGF pre- and posttransplantation resulted in long-term survival and phenotypic differentiation of these cells as well as an enhanced functional response. Subsequent studies employing cografts of NGF-producing cells confirmed the ability of NGF to promote robust chromaffin cell survival (Bing et al., 1990; Date et al., 1990a,b; Kordower et al., 1990a,b; Cunningham et al., 1991) and, in some instances, potentiate the magnitude and duration of functional effects (Bing et al., 1990). Based in part upon these studies, clinical trials employing adrenal medullary transplants coupled with NGF infusion (Olson et al., 1991) or cografts of NGF-producing tissues (C. Goetz and R. Bakay, personal communication) are currently being evaluated.

Although exposing adrenal medullary implants to NGF potentiates their viability, this fact does not provide direct evidence that the converse, low levels of endogenous NGF, mitigates poor graft survival. Indeed, Sagen and coworkers have demonstrated that chromaffin cells survive grafting into a number of brain regions without growth factor supplementation, when the chromaffin cells are isolated from the fibroblasts, endothelial cells, and blood-borne leukocytes normally found within the in situ adrenal medulla (Sagen et al., 1987, 1990; Pappas and Sagen,
1988; Ortega et al., 1992a,b). In the present experiments, we found that isolated chromaffin cells survive well following intrastriatal transplantation. In contrast, the presence of fibroblasts and endothelial cells derived from the adrenal medulla causes the transplants to degenerate. Therefore, these data do not support the contention that chromaffin cell viability is dependent upon trophic factor availability. Rather, we presently hypothesize that the presence of nonchromaffin cell types of thc adrenal medulla is deleterious to the viability of grafted chromaffin cells, and with their elimination, significant graft survival can be achieved.

\section{Materials and Methods}

Subjects. A total of 47 adult female Sprague-Dawley rats (250-300 gm) were used as graft recipients. All animals were housed in groups of two or three rats in cages kept in a virus-free room. Food and water were available ad libitum and animals were maintained on a $12 \mathrm{hr}$ on, $12 \mathrm{hr}$ off light-dark cycle. Rats were randomized into four implant groups: group 1 received implants of dispersed adrenal medullary suspensions from perfused bovine adrenal glands, group 2 received implants of isolated adrenal chromaffin cells, group 3 received implants of isolated adrenal chromaffin cells that were then reseeded with other nonchromaffin cell types of the adrenal medulla (fibroblasts and endothelial cells), and group 4 received implants of only fibroblasts and endothelial cells. Details of the cell isolation procedure are described below. Rats in groups 1-3 were killed 1 or 2 months following implantation. At both time points, each group consisted of six to nine rats. Rats in group $4(n=2)$ were killed 1 month posttransplantation. All rats were immunosuppressed with daily injections of cyclosporin $A(10 \mathrm{mg} / \mathrm{kg}$, i.p.) beginning the day of implantation and continuing for the duration of the experiment.

Adrenal chromaffin cell isolation. Bovine adrenal glands were utilized as donor material. Bovine cells were chosen for study because a significant number of chromaffin cells are lost during the isolation procedure and the bovine adrenal gland provides for a large initial population of cells. The glands were trimmed of their fat and perfused with a calcium/ magnesium-free Locke's solution $\left(1.5 \mathrm{M} \mathrm{KCl}, 0.04 \mathrm{M} \mathrm{NaHCO}_{3}, 0.06 \mathrm{M}\right.$ glucose, $0.05 \mathrm{M}$ HEPES at $\left.\mathrm{pH} 7.2,37^{\circ} \mathrm{C}\right)$ containing antibiotics $(100$ $\mathrm{U} / \mathrm{ml}$ penicillin/streptomycin, $25 \mathrm{mg} / \mathrm{ml}$ kanamycin) and antifungal agents $(0.125 \mathrm{mg} / \mathrm{ml}$ fungizone). The glands were incubated in the Locke's solution for $30 \mathrm{~min}$, and then perfused for another $30 \mathrm{~min}$ with a $0.1 \%$ collagenase solution [Boehringer-Mannheim; 0.05\% BSA (Sigma) and $0.01 \%$ trypsin inhibitor (Sigma)]. The medullary tissue was then dissected from the surrounding cortex, minced, filtered through a fine nylon mesh, and washed several times with the Locke's solution. At this point in tissue preparation, group 1 received implants of the resultant cell suspension. For groups $2-4$, bovine chromaffin cells were isolated from the nonchromaffin cell types as previously described (e.g., Sagen et al., 1987, 1990; Ortega et al., 1992a,b; Fig. 1). Briefly, the washed cells were suspended in a Percoll buoyancy gradient $(45 \mathrm{ml}$ Percoll, $5 \mathrm{ml}$ of $10 \times$ Locke's solution at pH 7.4) and spun at $12,000 \mathrm{rpm}$ for $25 \mathrm{~min}$ in a refrigerated centrifuge (IEC B20; $4^{\circ} \mathrm{C}$ ). This produces several bands with dense cell types (e.g., red blood cells) on the bottom, viable cell types (adrenal medullary cells) in the middle, and lysed cell fragments layering the top. The band containing the adrenal chromaffin cells was removed and washed with Locke's solution. The cells were then plated on 100 $\mathrm{mm}$ tissue culture plates with 1:1 Dulbecco's modified Eagle's medium : F12 medium containing 5\% fetal bovine serum and antibiotics, (penicillin/streptomycin, $100 \mathrm{U} / \mathrm{ml}$; gentamicin, $50 \mathrm{U} / \mathrm{ml}$ ). The plates were incubated overnight $\left(37^{\circ} \mathrm{C}, 5 \% \mathrm{CO}_{2}\right)$ to allow for the supporting cell types (endothelial cells and fibroblasts) to adhere to the culture plate. On the following day, the chromaffin cells were gently agitated from the plates and placed on a second Percoll gradient to purify the chromaffin cell population further. The viability of this cell preparation was in excess of $95 \%$ when tested for trypan blue exclusion. Supporting cells remaining on the plates were refed and allowed to grow for 3-5 d. Group 2 received the isolated chromaffin cells, groups 3 received isolated chromaffin cells that were then recombined with autologous fibroblasts and endothelial cells, and group 4 received implants of fibroblasts and endothelial cells alone.

Transplant surgery. All animals were anesthetized (Nembutal, $30 \mathrm{mg}$ / 
Figure 1. Method of chromaffin cell isolation. The adrenal medulla is first dissected from the surrounding adrenal cortex. The medulla is then placed in a Percoll buoyancy gradient that segregates the cells based upon cell density. The viable medullary cell types are then plated. Due to a differential adherence to the plates, tapping the back of the plates induces the chromaffin cells to be displaced while the fibroblasts and endothelial cells remain plated. This is done a few times, resulting in a $95 \%$ pure population of chromaffin cells, which are then resuspended and grafted into the host striatum. See Materials and Methods for further details.
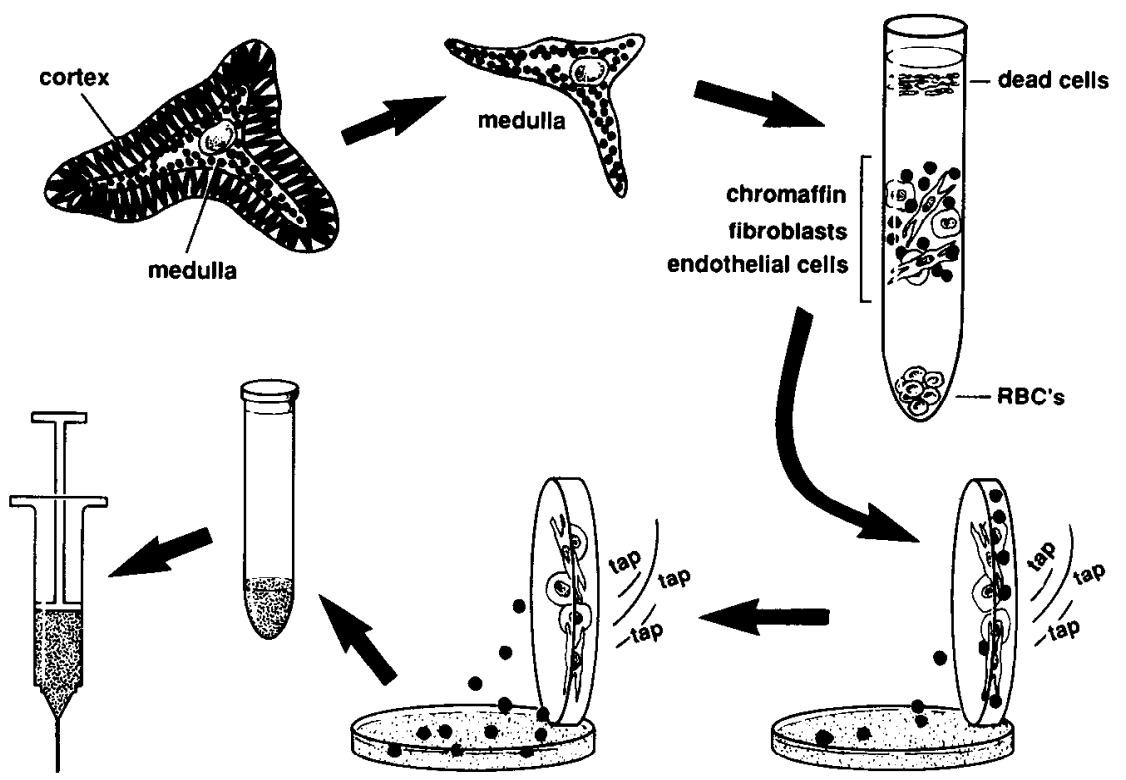

$\mathrm{kg}$, i.p.) and placed in the (Kopf) stereotaxic instrument. The skin was incised with an 11 scalpel blade and the cranial fascia was retracted. The coordinates for the transplant (Paxinos and Watson, 1986) were $0.48 \mathrm{~mm}$ anterior to the bregma suture, $3.5 \mathrm{~mm}$ lateral to the midsagittal suture, and $7.0 \mathrm{~mm}$ below the surface of the skull. A craniotomy was made using a high-speed dental drill. A $5 \mu$ l Hamilton syringe with a 26 gauge beveled needle was then mounted on the electrode holder and lowered into the left striatum. Each transplant was made in a $3 \mu \mathrm{l}$ vol over a $10 \mathrm{~min}$ period at a concentration of $75,000 \mathrm{cells} / \mu \mathrm{l}$. The needle was left in place an additional $5 \mathrm{~min}$ to allow the infusate to diffuse off the needle tip. The craniotomy was covered with Gelfoam and the skin closed with wound clips.

Preparation of tissues. Animals were killed 1 or 2 months following transplantation. Following anesthetization with Nembutal $(50 \mathrm{mg} / \mathrm{kg}$, i.p.), rats received a transcardiac perfusion with saline $(0.9 \%, 250 \mathrm{ml})$ followed by fixation with $400 \mathrm{ml}$ of $4 \%$ paraformaldehyde. Brains were then removed and cryoprotected by immersion in a $30 \%$ sucrose $/ 0.1 \mathrm{M}$ phosphate-buffered saline solution. Frozen sections $(40 \mu \mathrm{m})$ were cut in the coronal plane on a sliding knife microtome and stored in a cryoprotectant solution (Watson et al., 1986).

Immunocytochemistry. Sections were processed for the light microscopic visualization of tyrosine hydroxylase (TH), dopamine $\beta$-hydroxylase $(\mathrm{D} \beta \mathrm{H})$, phenylethanolamine $n$-methyl transferase (PNMT), and chromogranin $A$ according to previously published procedures (Fiandaca et al., 1988; Kordower et al., 1988, 1990b, 1991). Briefly, endogenous peroxidase activity was eliminated with a $20 \mathrm{~min}$ incubation in $0.1 \mathrm{M}$ sodium periodate. Background staining was then inhibited by a $1 \mathrm{hr}$ incubation in 3\% normal goat serum and $2 \%$ bovine serum albumin, after which the tissue was incubated in either $\mathrm{TH}, \mathrm{D} \beta \mathrm{H}$, or PNMT primary antiserum at a concentration of 1:2000 (Eugene Tech., Allendale, NJ) or chromogranin A (Immunonuclear Corp.) at a concentration of 1:1000. The immunohistochemical procedure continued using the labeled antibody procedure (Hsu et al., 1981). Sections were sequentially incubated in the biotinylated goat anti-rabbit IgG (Vector Labs; 1:100) and the Elite avidin-biotin complex (ABC Kits, Vector Labs; 1:1000) separated by washes in a Tris-buffered saline solution containing $0.05 \%$ Triton X-100. For most sections, the chromogen solution that completed the reaction consisted of $0.05 \%$ 3',3-diaminobenzidine (DAB), $0.005 \% \mathrm{H}_{2} \mathrm{O}_{2}$, and $2.5 \%$ nickel II sulfate, resulting in a blue-black reaction product. Selected sections were processed identically except that nickel II sulfate was omitted from the chromogen solution, resulting in a brown reaction product. Sections were then mounted on gelatin-coated slides, dehydrated through graded alcohols $(70 \%, 95 \%$, $99 \%$ ), cleared in xylenes, and coverslipped with Permount. Control sections for $\mathrm{TH}, \mathrm{D} \beta \mathrm{H}, \mathrm{PNMT}$, and chromogranin A immunoreactivity were processed in an identical fashion except for deletion of the primary antibody or substitution for the primary antibody with an irrelevant IgG. It should be noted that even though control sections failed to display specific immunoreactivity, the potential for antiserum to crossreact with structurally related proteins cannot be excluded. Thus, a degree of caution that is inherent to immunohistochemical procedures is warranted. In this regard, the term "immunoreactivity" in this study refers to "like" immunoreactivity.

Quantitation. Quantitation of graft area was determined on $\mathrm{D} \beta \mathrm{H}-$ immunostained sections. These sections were analyzed with the IMAGE 1200 morphometrics program (NIH) and Scion 1200 frame grabber interfaced with a Macintosh CX computer. The transplant was captured by the IMAGE program. The outline of each chromaffin cell cluster was then traced with the mouse and the total area of grafted chromaffin cells was determined. Large blood vessels and rarifications in chromaffin cell clusters were also measured and subtracted from the total graft area. Every sixth section through the transplant was evaluated. Therefore, the sum graft area for each animal was multiplied by 6 to obtain the total graft area per animal.

Statistics. Differences in graft area between groups were determined by a univariate analysis of variance (ANOVA) and, where appropriate, the Neuman-Keuls post hoc test. The null hypothesis was rejected when $p<0.05$.

\section{Results}

In $\mathrm{TH}$ - and $\mathrm{D} \beta \mathrm{H}$-immunoreacted sections, specific patterns of dopaminergic and noradrenergic neurons and fibers were observed in well-established catecholaminergic regions of the neuraxis. Furthermore, when chromaffin cells survived (see below) they were darkly immunoreactive for each chromaffin cell marker including $\mathrm{TH}, \mathrm{D} \beta \mathrm{H}, \mathrm{PNMT}$, and chromogranin A (see Fig. 6 ). In contrast, sections processed with the primary antibody deleted or with an irrelevant IgG failed to display immunoreactivity.

A significant difference in the viability of intrastriatally grafted chromaffin cells, as determined by graft area, was observed across the experimental conditions (Fig. 2). ANOVA revealed significant differences in graft area across the three transplant conditions $[F(2,10)=17.31 ; p<0.001]$. In rats receiving implants of dissociated adrenal medulla that contained bovine chromaffin cells, fibroblasts, and endothelial cells, a modest survival of the chromaffin cells was observed. Ten of 13 rats in this group displayed some viable grafted cells 1 and 2 months postimplantation. However, chromaffin cell survival in these grafts was inconsistent and highly variable. While an appreciable number of grafted chromaffin cells could be seen in a few animals (e.g., 
ENHANCED SURVIVAL OF CHROMAFFIN CELLS FOLLOWING IN VITRO ISOLATION: GRAFT AREA

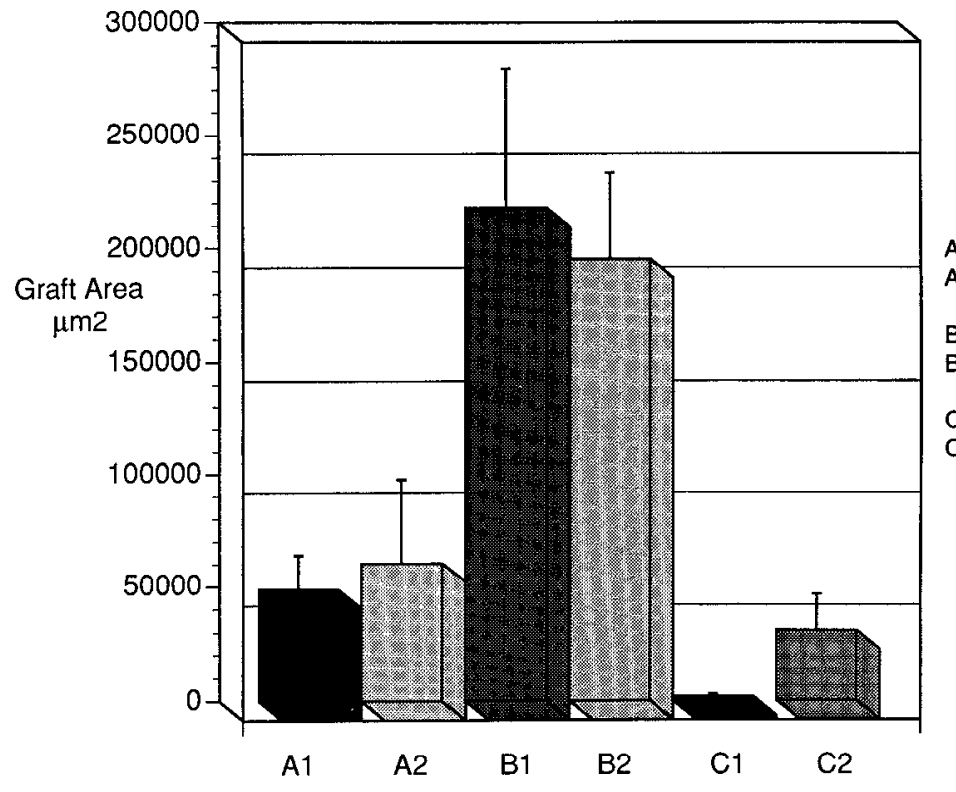

\section{Test Groups \\ A1 Perfused Only [1 mo.] A2 Perfused Only [2 mo.]}

B1 Isolated Chromaffin Cells [1 mo.] B2 Isolated Chromaffin Cells [2 mo.]

C1 Reseeded Medulla [1 mo.] C2 Reseeded Medulla [2 mo.]
Fig. 7C), many implants displayed few, if any, viable chromaffin cells (Figs. $3 A, B$ ). Of the cells that did survive, many displayed abnormal morphological profiles indicative of degenerative processes (see Fig. 7C). Many of these cells were shrunken, with damaged cell membranes. Some grafts contained a few viable chromaffin cells interspersed with degenerating cells and neural debris (see Fig. 7C). Furthermore, numerous hemosiderin-containing macrophages were observed in the perigraft region of rats receiving dissociated adrenal medulla implants (Fig. 3C), suggesting that an active degenerative process may be underway. However, it should be noted that a significant difference in chromaffin cell viability was not observed between 1 and 2 months postimplantation in this group $(p>0.05)$.

In contrast, rats receiving implants of isolated bovine chromaffin cells consistently exhibited large robust grafts (Figs. $4 A-$ $F ; 5 A-D ; 6 A, B ; 7 A, B)$. These cells were observed in both large and small clusters that tended to follow the shape of the needle tract. Some of these graft clusters were so large that they occupied space throughout the dorsoventral extent of the striatum (Figs. $4 A, B, D, E$ ). All 16 rats in this group displayed large viable grafts. The area of grafted chromaffin cells following isolation was significantly greater than that seen following dissociated adrenal medullary transplants both 1 month $(p<0.01)$ and 2 months $(p<0.01)$ posttransplantation. These cells were darkly immunoreactive for all chromaffin cell markers including TH (Fig. $5 A$ ), D $\beta \mathrm{H}$ (Fig. $5 B$ ), PNMT (Fig. $5 C$ ), and chromogranin A (Fig. $5 D$ ). The grafted chromaffin cell retained an endocrine phenotype and did not transform into sympathetic appearing neurons (Figs. $6 A, B ; 7 A, B$ ). In addition to an increase in graft size, isolated chromaffin cell implants appeared healthier with more normal morphological characteristics (Figs. 6; 7A,B) relative to animals receiving implants of dissociated adrenal medulla (Fig. 7C). These perikarya displayed smooth, round somata bearing continuous smooth cell membranes and looked remarkably similar to chromaffin cells observed in situ. More importantly, the graft and the perigraft region were virtually devoid of macrophages and reactive gliosis.

To control for the culture conditions used in chromaffin cell isolation, rats received implants of isolated chromaffin cells that were then recombined with their supporting cells (endothelial cells and fibroblasts). These rats exhibited minimal graft survival (Figs. 2, $8 A-D$ ). Indeed, only 7 of 17 rats displayed any surviving grafted chromaffin cells at all. This limited survival was significantly less than that observed in rats receiving isolated chromaffin cells ( $p<0.001$ at both 1 and 2 months). Interestingly, these grafts contained even fewer chromaffin cells than rats receiving implants of perfused adrenal medulla $(p<0.05$ at both 1 and 2 months). The perigraft region was often a site of immunological response displaying significant macrophage infiltration. Some graft sites appeared to be present but were virtually devoid of viable chromaffin cells. Other graft sites only displayed residual scar tissue and the graft itself appeared to have been essentially resorbed (Figs. $8 A-D$ ).

TH-immunoreacted sections revealed that implants of isolated chromaffin cells that were reseeded with autologous fibroblasts and endothelial cells induced a transient sprouting of host dopaminergic mesostriatal fibers. All rats in this group that were killed 1 month postimplantation displayed a robust plexus of host-derived TH-immunoreactive fibers within the perigraft region (Fig. 9A). These fibers were both of normal and thickened caliber (Fig. 9C) relative to the normal striatum (Fig. 9D) and often coursed through the implant site (Fig. $9 A, C$ ). This increase in host TH-immunoreactive fibers was observed for up to 1.3 $\mathrm{mm}$ distal to the implant. The sprouting response was greatly reduced in animals killed 2 months following transplantation and at this time was principally limited to the graft-host interface and a few TH-immunoreactive fascicles penetrating the graft for short distances (Fig. $9 B$ ). In contrast to TH immunohistochemistry, this sprouting response was negative for $\mathrm{D} \beta \mathrm{H}$ (Fig. $9 E$ ), indicating that the sprouted fibers were dopaminergic and not derived from central noradrenergic or peripheral sympathetic sources. Remarkably, this effect was never seen in rats receiving either dissociated adrenal medullary cells or isolated chromaffin cell implants.

No TH-immunoreactive somata were seen within the graft site of rats receiving implants of fibroblasts and endothelial cells 


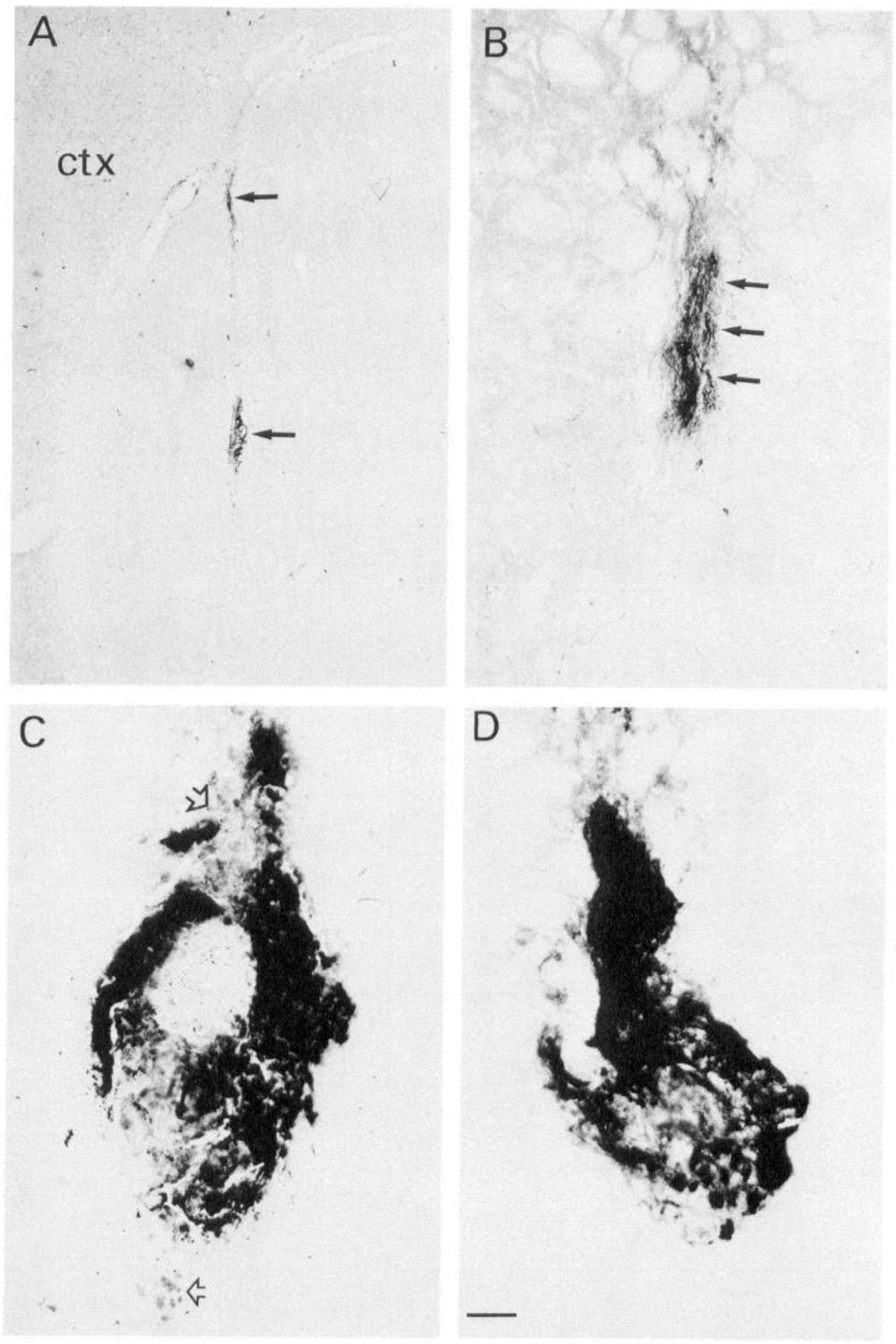

Figure 3. A, Low-power photomicrograph through the $\mathrm{D} \beta \mathrm{H}$-immunostained striatum of a rat receiving a suspension graft of dissociated adrenal medulla containing all medullary cell types. $B$, Higher-power view of a slightly more caudal section through the same transplant. Note the paucity of surviving chromaffin cells 1 month postimplantation. $C$ and $D$, High-power photomicrographs from other dissociated adrenal medullary transplants illustrating that the few viable chromaffin cells appear to be in the process of degeneration. Open arrows depict macrophages in the graft area. ctx , cortex. Scale bar: $200 \mu \mathrm{m}$ for $A, 100 \mu \mathrm{m}$ for $B$, and $50 \mu \mathrm{m}$ for $C$ and $D$.

alone. Interestingly, no host-derived TH sprouting response was observed in these rats.

\section{Discussion}

The present study clearly indicates that grafts of adrenal chromaffin cells can survive in large numbers within the rodent striatum without exposure to NGF. The viability of the chromaffin cell implants was directly related to the absence of fibroblasts and endothelial cells within the graft. Chromaffin cells survived well when they were isolated from the nonchromaffin cell types of the adrenal medulla. In contrast, the inclusion of fibroblasts and endothelial cells within the transplant, either by grafting adrenal medullary suspensions or by recombining the support cells with autologous isolated chromaffin cells, resulted in degeneration of the implant. Isolated chromaffin cell transplants were three- to fourfold larger in graft area relative to suspension grafts containing all medullary cell types. Indeed, the magnitude of this difference in chromaffin cell viability between isolated chromaffin cell grafts and suspension adrenal medullary grafts is likely an underestimate since quantitation was based upon measurements of graft area and the latter implants were composed of immunoreactive debris interspersed among viable, but degenerating, chromaffin cells.

The viability of intrastriatally grafted chromaffin cells stands in contrast to numerous previous studies that had generated a consensus that chromaffin cells survive poorly following grafting 


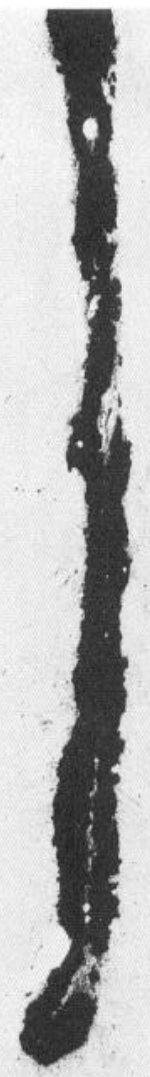

D

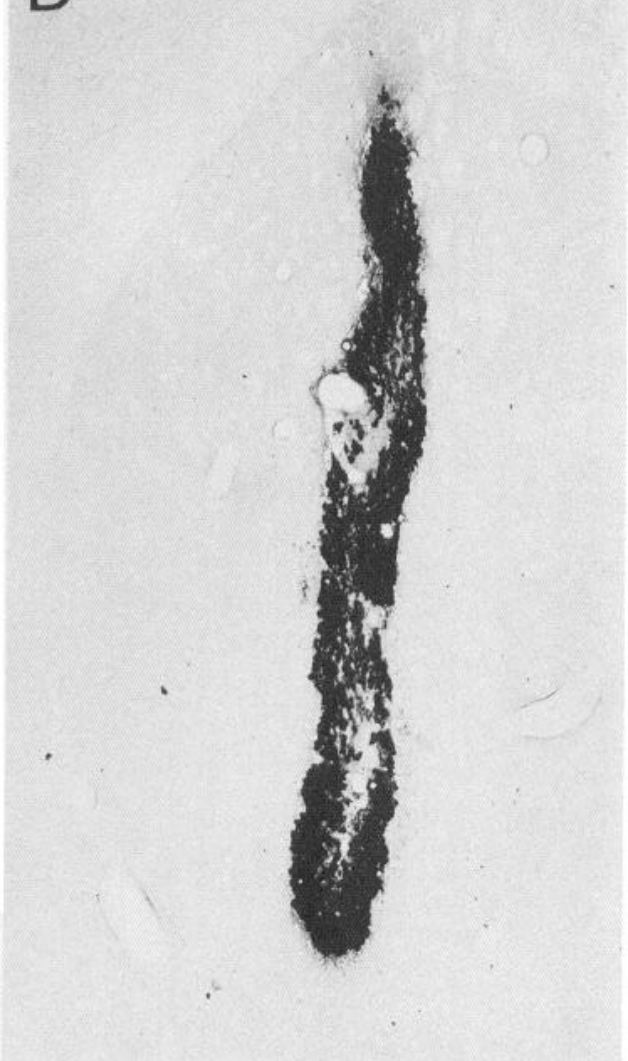

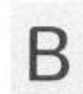
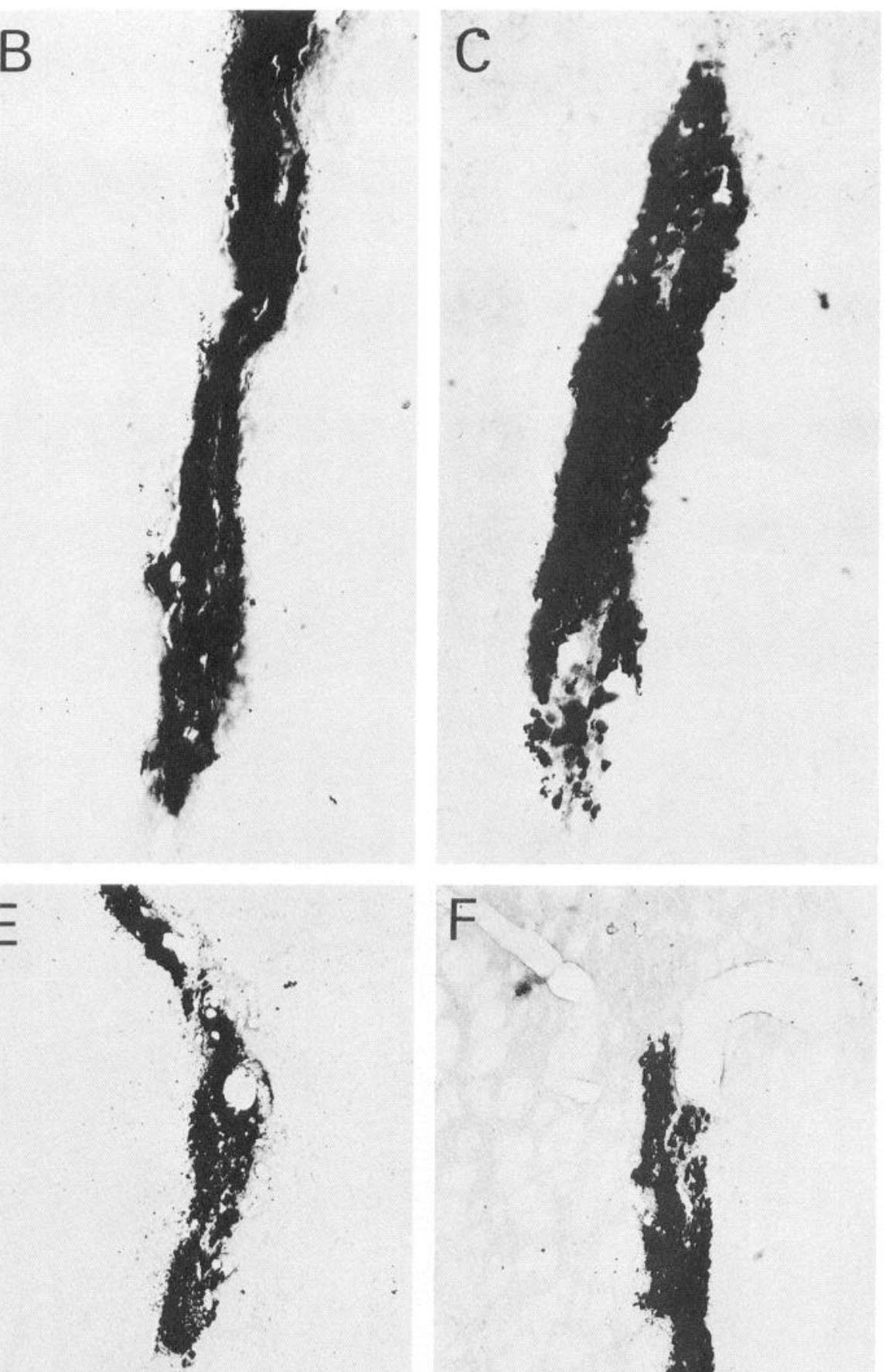
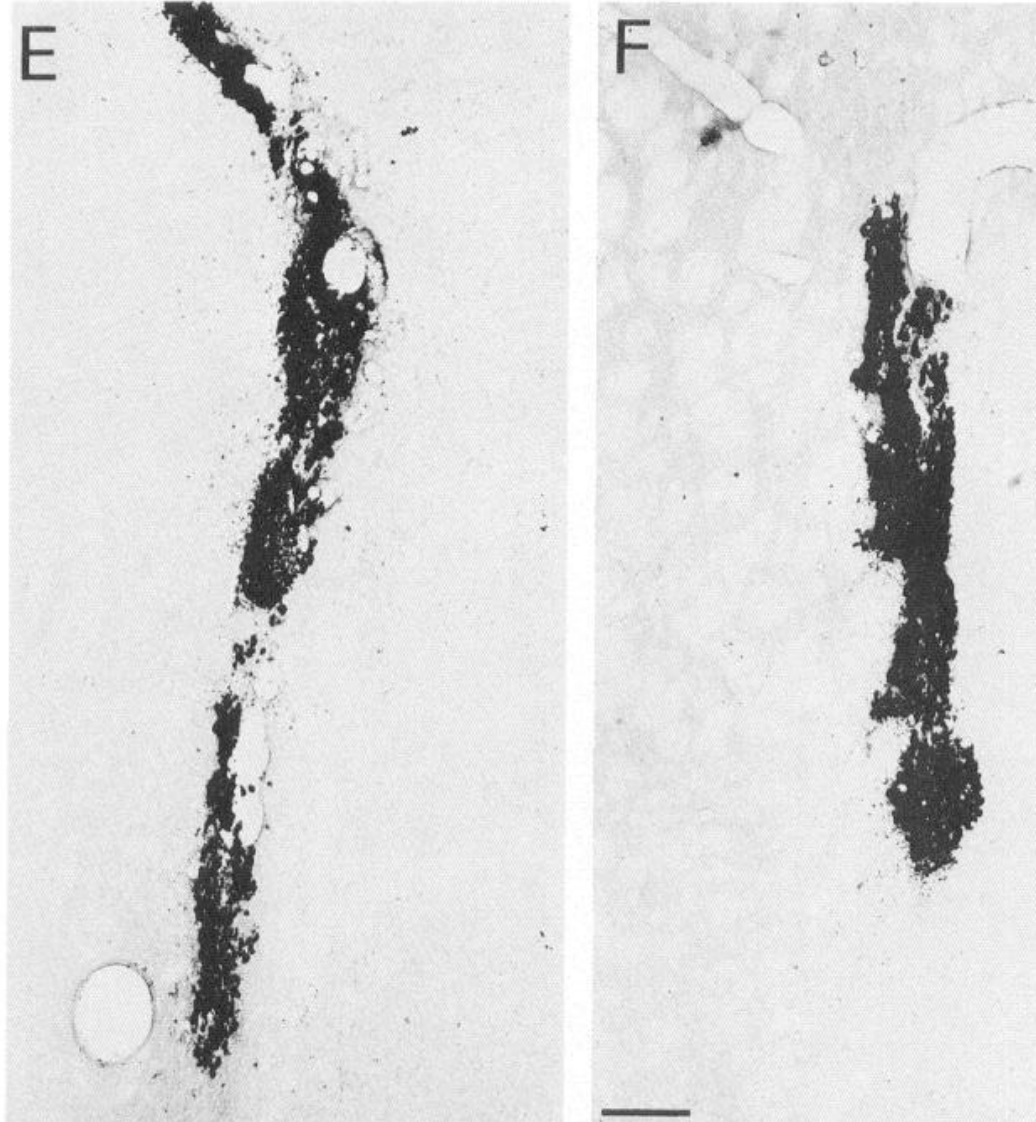

Figure 4. Low-power photomicrographs through the $\mathrm{D} \beta \mathrm{H}$-immunostained striatum from individual rats receiving isolated chromaffin cell transplants and killed 1 month $(A-C)$ or 2 months $(D-F)$ following transplantation. Note the consistently robust survival of adrenal chromaffin cells and the healthy graft-host interface. Scale bar, $200 \mu \mathrm{m}$ for $A-F$. 


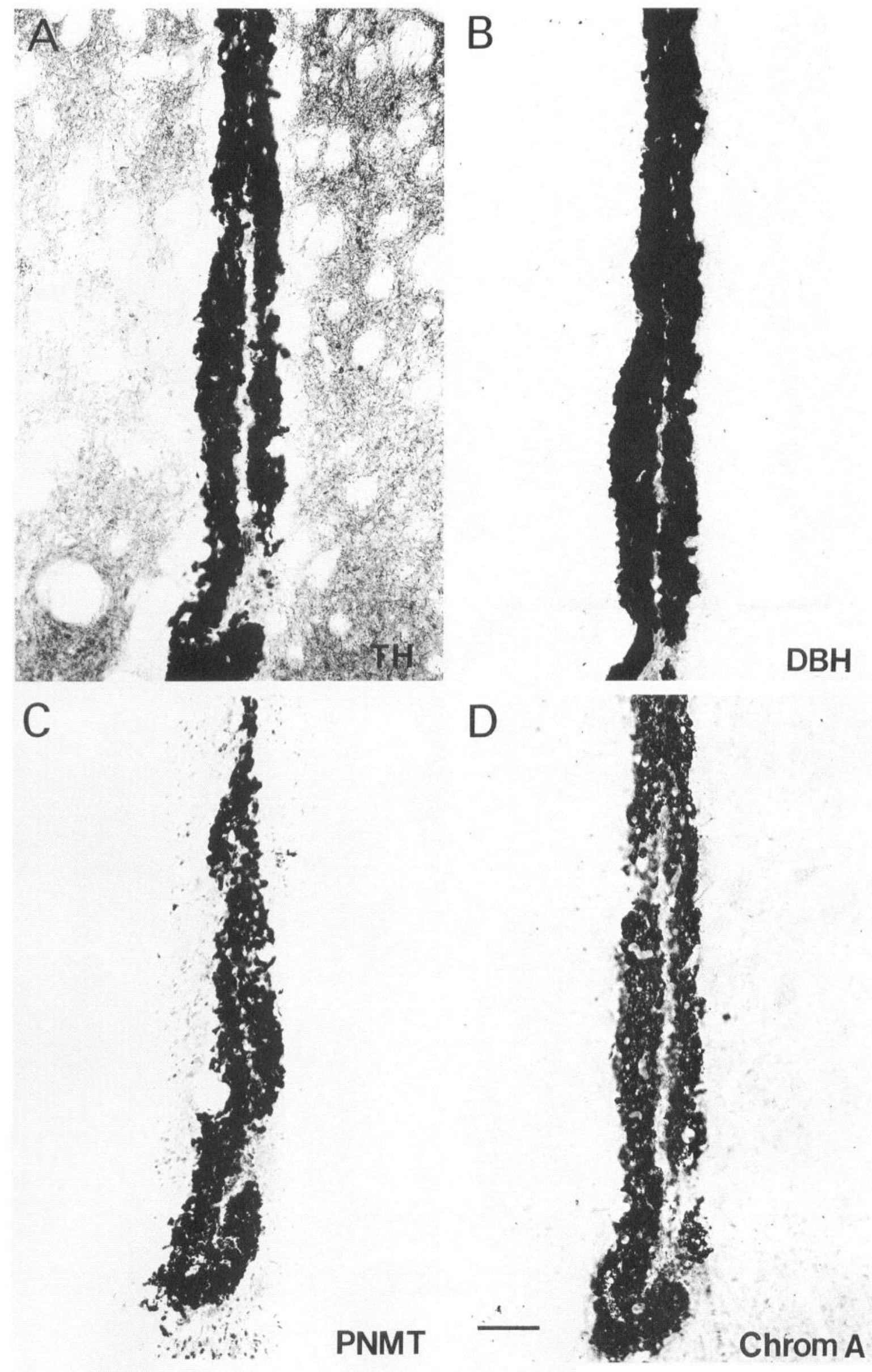



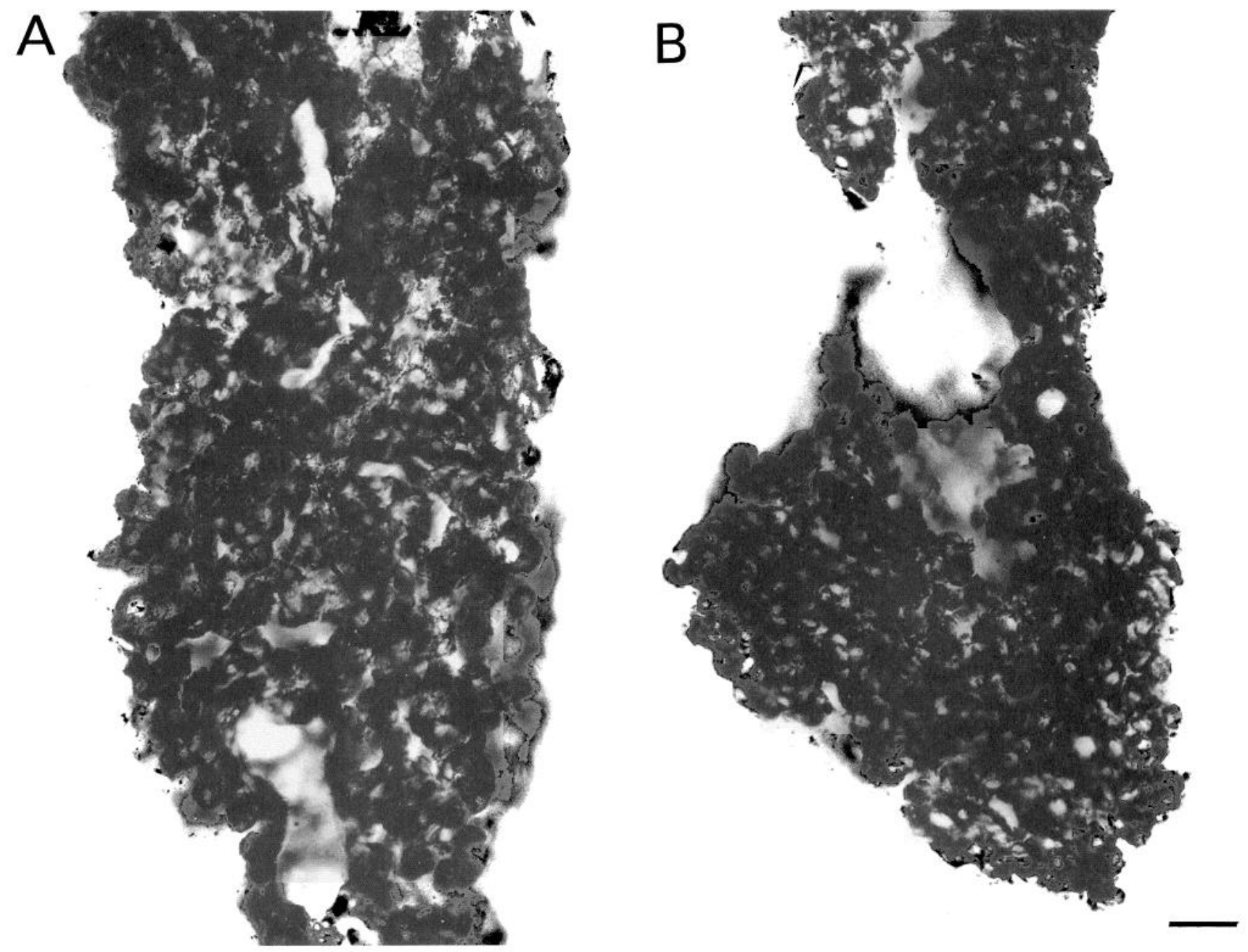

Figure 6. Medium-power photomicrographs of isolated adrenal chromaffin cells from two separate animals illustrating the rounded, healthy morphology of the grafted chromaffin cells. Scale bar, $66 \mu \mathrm{m}$ for $A$ and $B$.

within the striatum (Herrera-Marschitz et al., 1984; Morihisa et al., 1984; Strömberg et al., 1984; Freed et al., 1986; Bankiewicz et al., 1988; Hansen et al., 1988, 1989; Bing et al., 1990). For instance, Herrera-Marschitz et al. (1984) reported that chromaffin cells in solid grafts could only be observed with catecholamine histofluorescence for up to $400 \mathrm{~min}$ following grafting into the striatum of unilateral 6-hydroxydopamine-lesioned rats. Bing et al. (1990) grafted adrenal medullary cells in suspension, a technique that reliably enhances the survival of fetal neurons (Björklund et al., 1980), and found only modest numbers of viable adrenal chromaffin cells 1 month following implantation. Many other studies support the notion that adrenal medullary allografts survive poorly within the rodent striatum. The poor viability of grafted chromaffin cells does not appear to be directly related to immunological rejection of the transplant. A number of studies carried out in parkinsonian nonhuman primates have employed adrenal cell autografts to obviate immunological response to the paraneural graft. These studies have consistently reported poor viability of grafted cells (Morihisa et al., 1984;
Bankiewicz et al., 1988, 1990a; Hansen et al., 1988, 1989). Furthermore, all autopsy studies from Parkinson disease patients receiving adrenal chromaffin cell autografts have revealed poor chromaffin cell survival (Frank et al., 1988; Hurtig et al., 1989; Jankovick et al., 1989; Peterson et al., 1989; Hirsch et al., 1990; Waters et al., 1990), with only one case demonstrating a few viable TH-immunoreactive grafted cells (Kordower et al., 1991).

The poor survival of grafted adrenal chromaffin cells has been attributed to the low levels of endogenous NGF within the rodent and primate striatum. The experimental basis for this hypothesis principally stems from the observation that NGF supports the viability and phenotypic differentiation of adrenal chromaffin cells in vitro (Unsicker et al., 1978; see also Notter et al., 1989; Kordower et al., 1990a,b) and following intracerebral grafting (see reviews by Kordower et al., 1990b, 1992). Regarding neural grafting, the seminal study of Strömberg et al. (1985) demonstrated that large numbers of adrenal chromaffin cells survive for up to 1 year within the striatum, become mor-

Figure 5. Sequential sections through an isolated adrenal chromaffin cell transplant immunoreacted for TH $(A)$, D $\beta \mathrm{H}(B)$, PNMT $(C)$, and chromogranin A $(D)$. Scale bar, $100 \mu \mathrm{m}$ for $A-D$. 


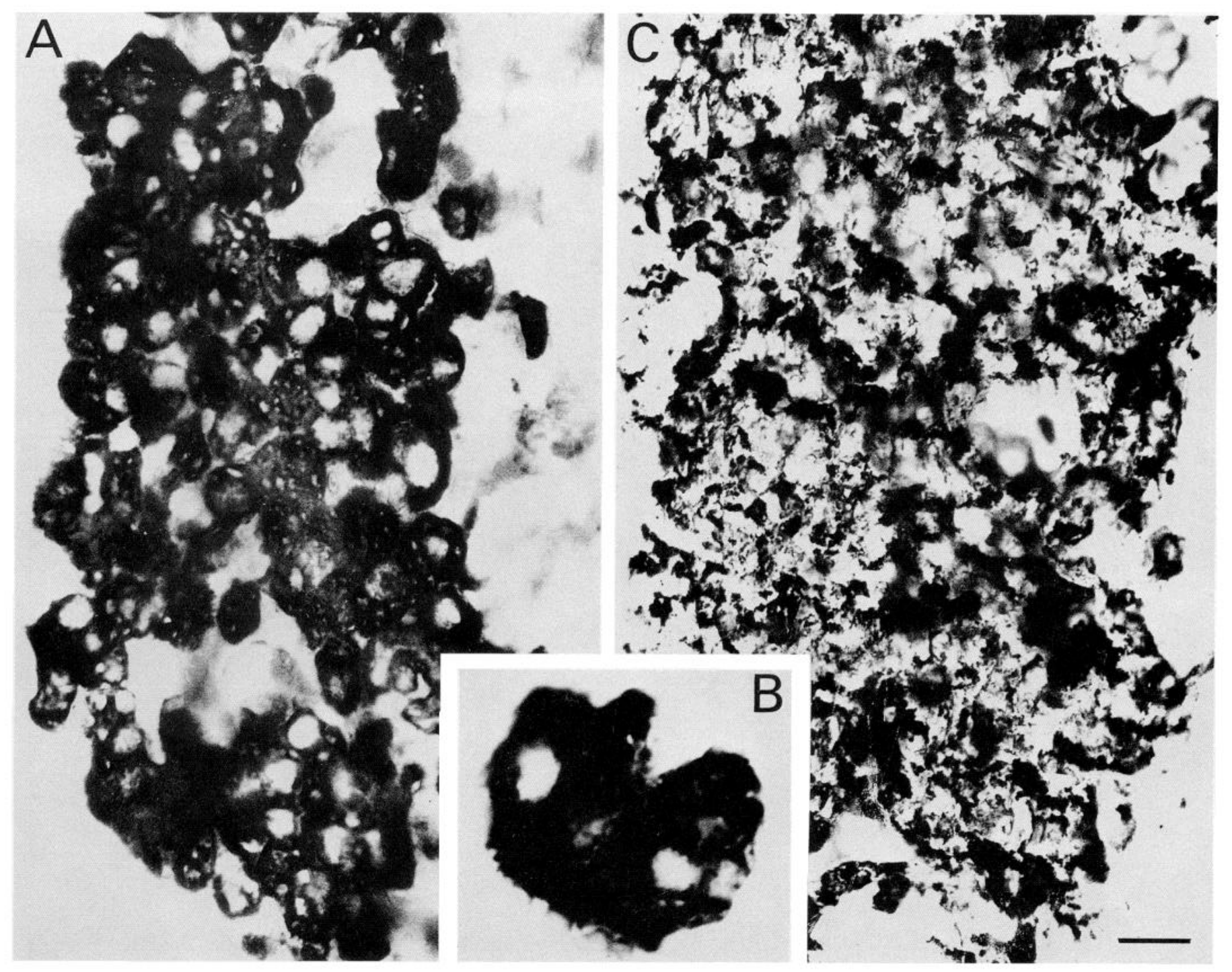

Figure 7. High-power $\mathrm{D} \beta \mathrm{H}$-immunoreactive sections illustrating the differing morphology of grafted chromaffin cells. $A$ and $B$, Note the healthyappearing morphology of isolated chromaffin cells 2 months following transplantation. $C$, In contrast, dissociated adrenal medullary grafts contain both healthy and degenerating chromaffin cells as well as cellular debris. Scale bar, $45 \mu \mathrm{m}$ for $A$ and $C$ and $75 \mu \mathrm{m}$ for $B$.

phologically differentiated, and potentiate functional recovery when the implant receives injections of $\beta$-NGF. We and others have demonstrated that cografting adrenal chromaffin cells with biological sources of NGF also enhances the viability of grafted chromaffin cells. In this regard, chromaffin cells cografted with growth factor-producing C6 gliomas (Bing et al., 1990), astrocytes or fibroblasts genetically engineered to produce NGF (Cunningham et al., 1991; Chalmers et al., 1992), or growth factorproducing transected peripheral nerve (Date et al., 1990a,b; Kordower et al., 1990b; Doering, 1991) potentiate the viability, and in some cases functionality, of adrenal medullary grafts. In addition, the improved survival of adrenal medullary grafts placed into brain regions that synthesize high levels of endogenous NGF such as the hippocampus (Jousselin-Hosaja, 1988a,b) and cerebral cortex (Morihisa et al., 1984) further supports the notion that low striatal levels of NGF are responsible for the poor survival of intrastriatal implants.

However, the fact that NGF can enhance adrenal graft viability does not necessarily prove the converse, that the poor survival of these implants results from insufficient trophic support. Indeed, significant numbers of chromaffin cells can survive intrastriatal implantation into nonhuman primates when the implants are sliced into "ribbons" prior to implantation, suggesting that factors other than trophic molecules are essential for the viability of grafted chromaffin cells (Dubach and German, 1990). We have recently demonstrated the survival of over $1,000,000$ isolated bovine chromaffin cells when grafted into the caudate and putamen of hemiparkinsonian monkeys (Schue-

Figure 8. Most implants of isolated adrenal chromaffin cells that were recombined with autologous fibroblasts and endothelial cells had completely degenerated, with few viable chromaffin cells (arrows) observed, 1 month posttransplantation. ctx, cortex. Scale bar: $200 \mu \mathrm{m}$ for $A, 100 \mu \mathrm{m}$ for $B$ and $C$, and $50 \mu \mathrm{m}$ for $D$. 

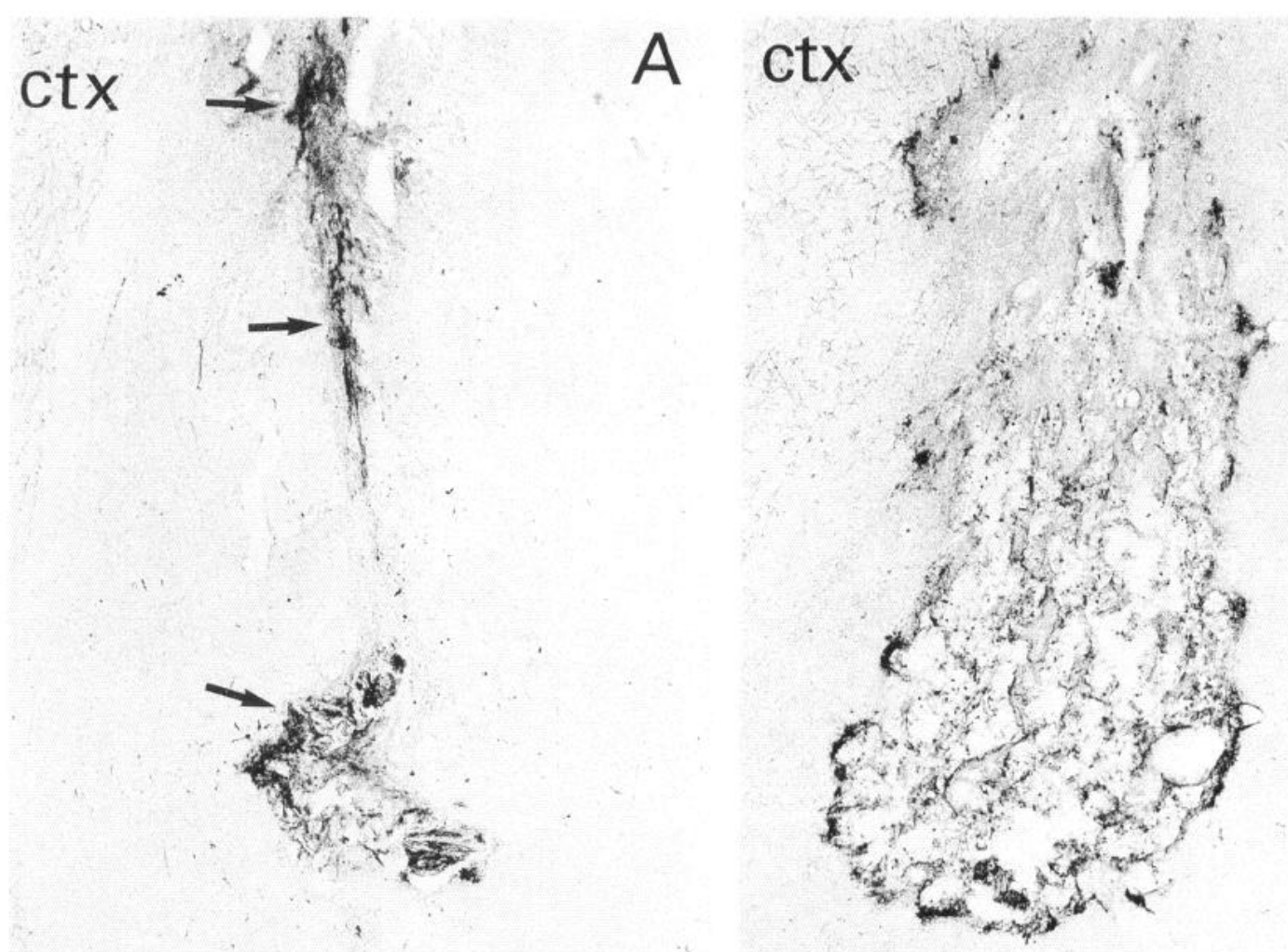

B
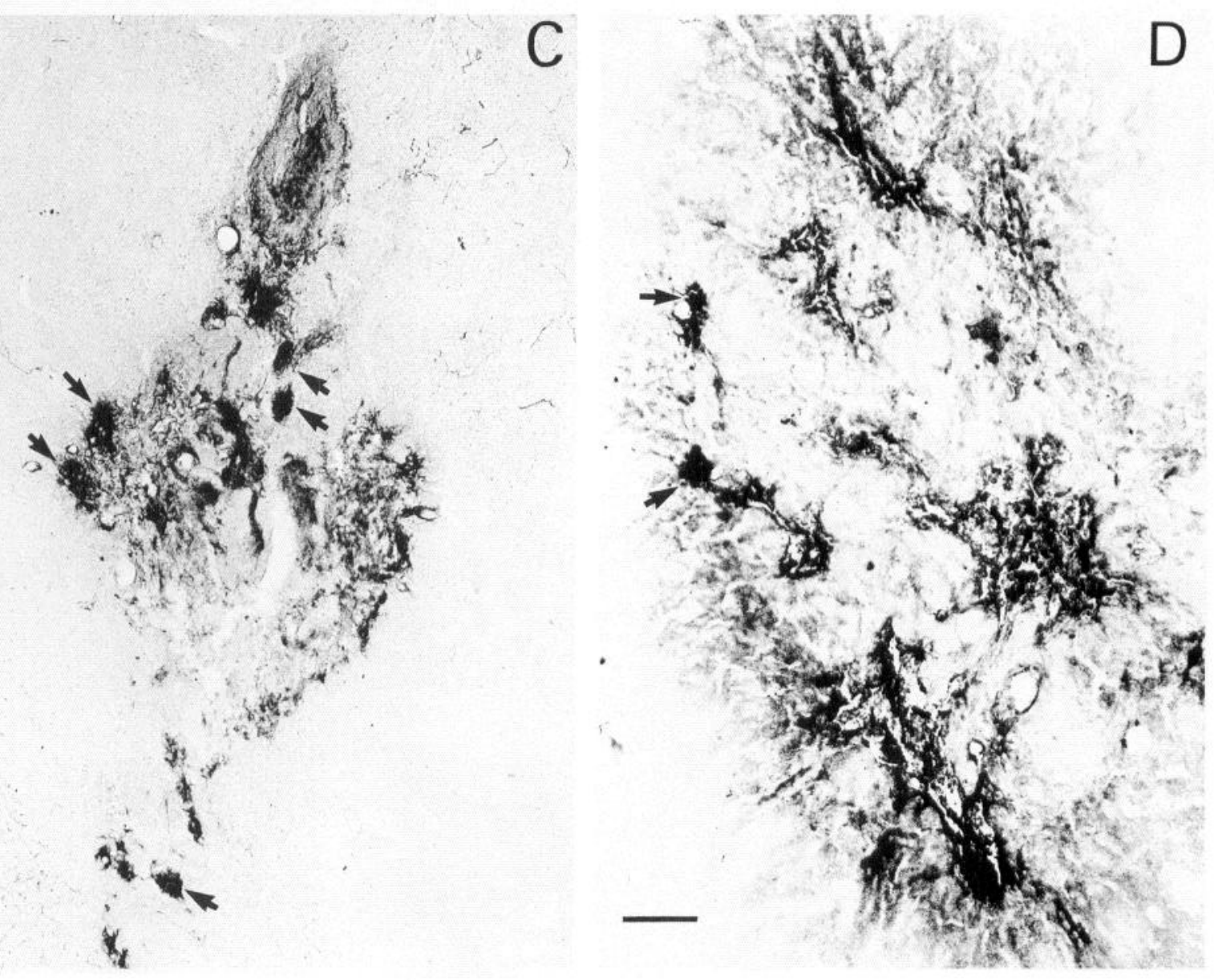

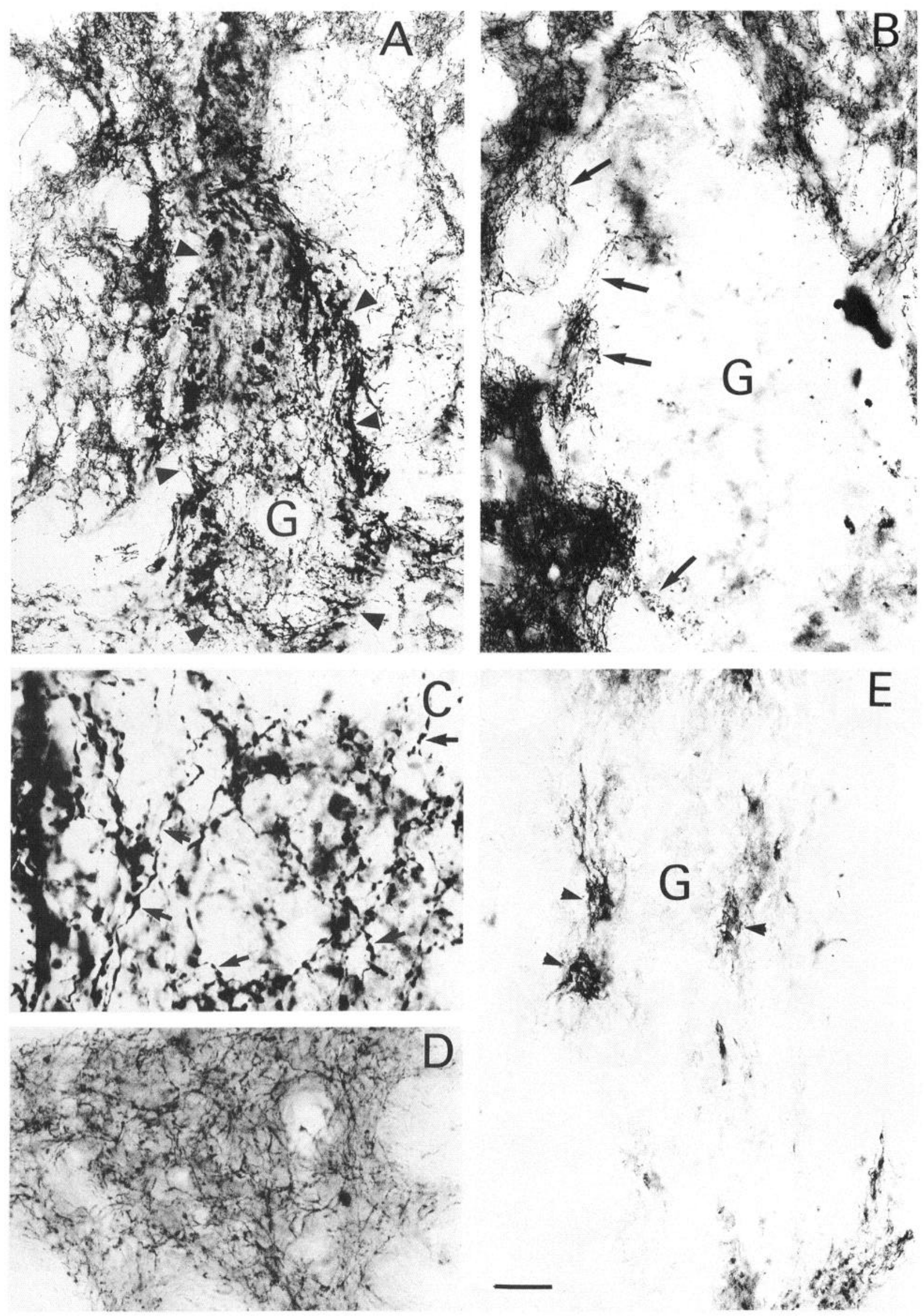
ler et al., 1992). Sagen and coworkers have consistently demonstrated excellent survival of chromaffin cells following grafting into a number of CNS sites such as the periaqueductal gray (Sagen et al., 1987, 1990; Pappas and Sagen, 1989; Ortega et al., 1992a,b), a brain region not recognized for containing high levels of neurotrophins (Korcshing et al., 1985). In these latter studies, the chromaffin cells were isolated from the nonchromaffin cell constituents of the adrenal medulla and were implanted as a relatively pure chromaffin cell population. These findings suggest that nonchromaffin cells of the adrenal medulla, such as the fibroblasts, endothelial cells, and blood-borne leukocytes, which are normally contained within an adrenal medullary graft, may be deleterious to the survival of the adrenal chromaffin cells.

The present study utilized this cell segregation procedure to determine whether isolation of the chromaffin cells from the other cell types within the adrenal medulla would enhance chromaffin cell viability following grafting into the NGF-poor striatum. When dissociated adrenal medullary suspensions containing all medullary cell types were grafted into the striatum, chromaffin cell viability was poor, as has been seen previously (see reviews by Freed et al., 1990; Kordower et al., 1990a, 1992). In contrast, robust survival of chromaffin cells was observed when the chromaffin cells were isolated from the fibroblasts, endothelial cells, and blood-borne leukocytes of the adrenal medulla. Dense clusters of grafted chromaffin cells could be seen extending from the corpus callosum to the ventral caudoputamen. Not only did these cells survive, but they also expressed all enzymatic markers for catecholamine synthesis as well as chromogranin A. At the light microscopic level, these cells displayed dense clustering with morphological features reminiscent of chromaffin cells observed in situ. Conversely, when isolated chromaffin cells were recombined with autologous fibroblasts and endothelial cells, the grafts degenerated. These data strongly support our hypothesis that it is not the lack of sufficient NGF support, but rather soluble factor(s) or physical characteristics specific to the nonchromaffin adrenal medullary cells that underlie the poor survival of intrastriatal adrenal medullary grafts.

Defining the cell type(s), as well as the molecule or molecules, responsible for poor adrenal medulla graft viability remains to be elucidated. It is unlikely that factors secreted by the fibroblasts and endothelial cells have direct toxic effect upon the chromaffin cells. Any potential toxic effects would suggest a de novo synthesis of neurotoxic molecules following grafting since fibroblasts and endothelial cells reside amiably with chromaffin cells within the in situ adrenal gland. It is possible that fibroblasts, endothelial cells, and/or blood-borne leukocytes induce the synthesis of endogenous neurotoxins or inhibiting factors within the striatum. However, this explanation would have to account for the fact that exposing chromaffin cells to NGF, via either injection (Strömberg et al., 1985) or cografting (Bing et al., 1988; Date et al., 1990a,b; Kordower et al., 1990a,b; Cun- ningham et al., 1991; Doering, 1991; Chalmers et al., 1992), is sufficient to counteract the effects of any potential endogenous neurotoxins.

A more likely explanation is that either physical characteristics and/or soluble factors secreted by the nonchromaffin cells of the adrenal medulla obstruct the integration of the graft with the host with respect to essential biological requirements such as vascularization and oxygenation. The vasculature proximal to isolated chromaffin cell transplants usually exhibits tight junctions and is nonfenestrated similar to the surrounding host CNS vessels (Ortega et al., 1992a,b). In contrast, adrenal medulla grafts containing other cell types are often vascularized by fenestrated vessels reminiscent of the in situ adrenal medulla (Krum and Rosenstein, 1987; Rosenstein, 1987, 1991; Sagen et al., 1987; Pappas and Sagen, 1988). Therefore, the presence of fibroblasts and endothelial cells within the adrenal medulla may govern the type of neovascularization within the graft and perigraft region, thus determining whether potentially deleterious blood-borne molecules can enter the graft microenvironment. Alternatively, it is possible that the presence of nonchromaffin cell types in the grafts (e.g., endothelial cells), which are notoriously antigenic, enhances the host immunological response, leading to graft rejection. This may occur even in cyclosporin A-treated rats since this immunosuppression treatment blocks only one arm of the immune response (Platt et al., 1991; Sedmak and Orosz, 1991).

An additional finding of this study was the induction of host TH-immunoreactive sprouting following implants of isolated chromaffir cells with reseeded fibroblasts and endothelial cells (group 3). The sprouted fibers are likely dopaminergic since they were immunoreactive for TII but not $\mathrm{D} \beta$ II. This sprouting effect was also time dependent. Robust TH-immunoreactive fiber plexuses were observed within the graft and perigraft region in all rats 1 month following transplantation. However, this effect was more modest and only observed in a few rats 2 months postimplantation. The temporal sequence of this effect suggests the possibility that blood-borne molecules entering the brain following graft-induced disruption of the blood-brain barrier induce the sprouting response, which attenuates following reclosure of the blood-brain barrier. Alternatively, factors secreted by scavenger cells or dying chromaffin cells may mediate this response. Indeed, only the most degenerative transplants that contained chromaffin cells induced this response, as implants containing fibroblasts and endothelial cells alone were without effect. Rats in group 3 displayed robust sprouting yet the poorest chromaffin cell survival. This is consistent with previous observations that TH-immunoreactive sprouting is seen within the striatum of parkinsonian monkeys (Bankiewicz et al., 1988; Fiandaca et al., 1988; Plunkett et al., 1990) and Parkinson's disease patients (Hurtig et al., 1989; Kordower et al., 1991) following adrenal autografts that degenerate soon after implantation or even following sham transplantation (Bankiewicz et al., 1988; Fiandaca et al., 1988; Plunkett et al., 1990).

\footnotetext{
Figure 9. Implants of isolated adrenal chromaffin cells recombined with autologous fibroblasts and endothelial cells induced a host-derived THimmunoreactive sprouting response. $A$, Dense TH immunoreactivity was observed within and surrounding (arrowheads) the graft $(G) 1$ month following transplantation. $B$, By 2 months postimplantation, this sprouting response was attenuated and was mostly observed at the graft-host interface, with few TH-immunoreactive fibers (arrows) penetrating into the graft $(G) . C$ and $D$, The sprouting TH-immunoreactive fibers were swollen and varicose $(C$, arrows) and appeared thicker than normal striatal TH-immunoreactive fibers $(D)$. $E$. Section through the same transplant illustrated in $A$ immunostained for $\mathrm{D} \beta \mathrm{H}$. While a few viable chromaffin cells could be seen (arrowheads), a $\mathrm{D} \beta \mathrm{H}$-immunoreactive fiber plexus was not observed within the graft $(G)$ or perigraft region. Scale bar: $100 \mu \mathrm{m}$ for $A$ and $E, 50 \mu \mathrm{m}$ for $B$, and $75 \mu \mathrm{m}$ for $C$ and $D$.
} 
It is important to note that the TH-immunoreactive fibers ramifying within the graft and perigraft region are likely due, in part, to the fact that implants were placed into nonlesioned rats with an intact nigrostriatal system. In animal models of Parkinson's disease that spare residual dopaminergic mesostriatal neurons, sprouting can be observed. In contrast, sprouting is never observed following comprehensive lesions of the substantia nigra and ventral tegmental area (see review by Kordower et al., 1992).

In summary, the present data demonstrate that adrenal chromaffin cells survive in large numbers following intrastriatal transplantation when isolated from the nonchromaffin cell types of the adrenal medulla. We propose that the poor survival of grafted chromaffin cells previously observed by our group (Hansen et al., 1988, 1989, 1990; Bing et al., 1990; Kordower et al., 1990a,b, 1991) and others (Herrera-Marschitz et al., 1984; Morihisa et al., 1984; Strömberg et al., 1984; Freed et al., 1986; Bankiewicz et al., 1988; Frank et al., 1988; Hurtig et al., 1989; Jankovick et al., 1989; Peterson et al., 1989; Hirsch et al., 1990; Waters et al., 1990) is not due to the lack of NGF-mediated trophic support as previously believed. Rather, the fibroblasts and/or endothelial cells within the adrenal medulla appear deleterious to the viability of adrenal medullary grafts, an effect that can be overcome by NGF administration (Strömberg et al., 1985) or cografting with growth factor-producing cells (Bing et al., 1988; Date et al., 1990a,b; Kordower et al., 1990a,b; Cunningham et al., 1991; Doering, 1991; Chalmers et al., 1992). Should clinical trials employing adrenal transplants for Parkinson's disease continue, even with trophic factor supplementation, strong consideration should be given to procedures aimed at chromaffin cell isolation.

\section{References}

Ahlskog JE, Kelly PJ, van Heirden JA, Stoddard SL, Tyce GM, Windebank AJ, Bailey PA, Bell GN, Blexrud MD, Carmichael SW (1990) Adrenal medullary transplantation into the brain for the treatment of Parkinson's disease: clinical outcome and neurochemical studies. Mayo Clin Proc 65:305-328.

Allen GS, Burns RS, Tulipan NB, Parker RA (1989) Adrenal medullary transplantation into the caudate nucleus in Parkinson's disease: initial clinical results in 18 patients. Arch Neurol 46:487-491.

Allen YS (1988) The influence of nerve growth factor treatment and endogenous growth factors on the survival of PC 12 cells grafted into the adult rat brain. In: Progress in brain rescarch, Vol 78, Transplantation into the mammalian CNS (Gash DM, Sladek JR Jr, eds), pp 637-642. Amsterdam: Elsevier.

Apuzzo MLJ, Neal JH, Waters CH, Appley AJ, Boyd SD, Couldwell WT, Wheelock VH, Weiner LP (1990) Utilization of unilateral and bilateral stereotactically placed adrenomedullary-striatal autografts in Parkinsonian humans: rationale, techniques, and observations. Neurosurgery 26:746-757.

Backlund EO, Granberg PO, Hamberger B, Knutsson E, Martensson A, Sedvall G, Seiger A, Olson L (1985) Transplantation of adrenal medullary tissue to striatum in parkinsonism. First clinical trials. I Neurosurg 62:169-173.

Bakay RAE, Barrow DL, Fiandaca MS, Iuvone PM, Schiff A, Collins DC (1987) Biochemical and behavioral correction of MPTP-like syndrome by fetal cell transplantation. Ann NY Acad Sci 495:623640.

Bankiewicz KS, Plunkett RJ, Kopin IJ, Jacobowitz DM, London WT, Oldfield EH (1988) Transient behavioral recovery in hemiparkinsonian primates after adrenal medullary allografts. In: Progress in brain research, Vol 78, Transplantation into the mammalian CNS (Gash DM, Sladek JR Jr, eds), pp 543-550. Amsterdam: Elsevier.

Bankiewicz KS, Plunkett RJ, Mefford I, Kopin IJ, Oldfield EH (1990a) Behavioral recovery from MPTP-induced parkinsonism in monkeys after intracerebral tissue implants is not related to CSF concentrations of dopamine metabolites. In: Progress in brain research, Vol 82, Neural transplantation from molecular basis to clinical application (Dunnett SB, Richards SJ, eds), pp 561-571. Amsterdam: Elsesvier.

Bankiewicz KS, Plunkett RJ, Jacobowitz DM, Porrino L, di Porzio U, London WT, Kopin IJ, Oldfield EH (1990b) The effect of fetal mesencephalon implants on primate MPTP-induced parkinsonism. Histochemical and behavioral studies. J Neurosurg 72:231-244.

Bing G, Notter MFD, Hansen JT, Gash DM (1988) Comparison of adrenal medullary, carotid body and PC12 ccll grafts in 6-OHDA lesioned rats. Brain Res Bull 20:399-406.

Bing G, Notter MFD, Hansen JT, Kellogg C, Kordower JH, Gash DM (1990) Cografts of adrenal medulla with $\mathrm{C} 6$ glioma cells in rats with 6-hydroxydopamine-induced lesions. Neuroscience 34:687-697.

Björklund A, Stenevi U (1979a) Reconstruction of the nigrostriatal dopamine pathway by intracerebral nigral transplants. Brain Res 177: $555-560$.

Björklund A, Stenevi U (1979b) Regeneration of monoaminergic and cholinergic neurons in the mammalian central nervous system. Physiol Rev 59:62-100.

Björklund A, Schmidt RH, Stenevi U (1980) Functional reinnervation of the neostriatum in the adult rat by use of the intraparencymal grafting of dissociate cell suspensions from the substantia nigra. Cell Tissue Res 212:39-49.

Björklund A, Stenevi U, Dunnett SB (1981) Functional reactivation of the deafferented neostriatum by nigral transplants. Nature 289: $497-499$.

Chalmers GR, Niijima K, Patterson PH, Peterson DA, Fisher LJ, Gage FH (1992) Chromaffin cells cografted with NGF-producing fibroblasts exhibit neuronal features. Soc Neurosci Abstr 18:782.

Cunningham LA, Hansen JT, Short MP, Bohn MC (1991) The use of genetically altered astrocytes to provide nerve growth factor to adrenal chromaffin cells grafted into the striatum. Brain Res 561:192-202.

Date I, Felten SY, Olschowka JA, Felten DL (1990a) Limited recovery of striatal dopaminergic fibers by adrenal medullary grafts in MPTPtreated aging mice. Exp Neurol 107:197-207.

Date I, Felten SY, Felten DL (1990b) Cografts of adrenal medulla with peripheral nerve enhance the survivability of transplanted adrenal chromaffin cells and recovery of the host nigrostriatal dopaminergic system in MPTP-treated young adult mice. Brain Res 537: 33-39.

Doering LC (1991) Transplantation of fetal CNS tissue into the peripheral nervous system: a model to study aberrant changes in the neuronal cytoskeleton. J Neural Transp Plast 2:193-205.

Dubach M, German DC (1990) Extensive survival of chromaffin cells in adrenal medulla "ribbon" grafts in the monkey neostriatum. Exp Neurol 110:167-180.

Dunnett SB, Björklund A, Stenevi U, Iverson SD (1981) Behavioral recovery following transplantation of substantia nigra in rats subjected to 6-OHDA lesions of the nigrostriatal pathway. I. Unilateral lesions. Brain Res 215:147-161.

Fiandaca MS, Kordower JH, Hansen JT, Jiao S-S, Gash DM (1988) Adrenal medullary autografts into the basal ganglia of Cebus monkeys: injury-induced regeneration. Exp Neurol 102:76-91.

Fine A, Hunt SB, Oertel WH, Nomoto M, Chong PN, Bond A, Waters C, Temlett JA, Annett L, Dunnett S, Jenner P, Marsden CD (1988) Transplantation of embryonic marmoset dopaminergic neurons to the corpus striatum of marmosets rendered parkinsonian by 1-methyl4-phenyl-1,2,3,6 tetrahydropyridine. In: Progress in Brain Research, Vol 78, Transplantation into the mammalian CNS (Gash DM, Sladek JR Jr, eds), pp 479-489. Amsterdam: Elsevier.

Frank F, Sturiale C, Gaist G, Manetto V (1988) Adrenal medulla autograft in a human brain for Parkinson's disease. Acta Neurochir (Wien) 94:162-163.

Freed WJ, Perlow MJ, Karoum F, Seiger A, Olson L, Hoffer BJ, Wyatt RJ (1980) Restoration of dopamine function by grafting of fetal rat substantia nigra to the caudate nucleus: long term behavioral, biochemical, and histolochemical studies. Ann Neurol 8:510-523.

Freed WJ, Morihisa M, Spoor HE, Hoffer B, Olson L, Seiger A, Wyatt RJ (1981) Transplanted adrenal chromaffin cells in rat brain reduce lesion-induced rotational behavior. Nature 292:351-352.

Freed WJ, Karoum F, Spoor HE, Morihisa JM, Olson L, Wyatt RJ (1983) Catecholamine content of intracerebral adrenal medulla grafts. Brain Res 269:184-189.

Freed WJ, Cannon-Spoor H, Krauthamer E (1985) Factors influencing 
the efficacy of adrenal medulla and embryonic substantia nigra grafts. In: Progress in brain research, $\mathrm{Vol} 82$, Neural grafting in mammalian CNS (Bjorklund A, Stenevi U, eds), pp 491-504. Amsterdam: Elsevier.

Freed WJ, Cannon-Spoor EH, Krauthamer E (1986) Intrastriatal adrenal medulla grafts in rats. J Neurosurg 65:664-670.

Freed WJ, Poltorak M, Becker JB (1990) Intracerebral adrenal medulla grafts: a review. Exp Neurol 110:139-166.

Goetz CG, Olanow CW, Koller WC, Penn RD, Cahill D, Morantz R, Stebbins G, Tanner CM, Klawans HL, Shannon KM, Comella CL, Witt T, Cox C, Waxman M, Gauger L (1989) Multicenter of autologous adrenal medullary transplantation to the corpus striatum in patients with advanced Parkinson's disease. N Engl J Med 320:337340.

Hansen JT, Kordower JH, Fiandaca MS, Jiao S-S, Notter MFD, Gash DM (1988) Adrenal medullary autografts into the basal ganglia of Cebus monkeys: graft viability and fine structure. Exp Neurol 102: 65-75.

Hansen JT, Bing G, Notter MFD, Kordower JH, Fiandaca MS, Gash DM (1989) Adrenal chromaffin cells as transplants in animal models of Parkinson's disease. J Electron Microsc Tech 12:308-315.

Hansen JT, Fiandaca MS, Kordower JH, Notter MFD, Gash DM (1990) Striatal adrenal medulla/sural nerve cografts in hemiparkinsonian monkeys. In: Progress in brain research, Vol 82, Neural transplantation from molecular basis to clinical application (Dunnett SB, Richards SJ, eds), pp 573-580. Amsterdam: Elsevier.

Hefti F, Hartikka J, Schlumpf M (1985) Implantation of PC12 cells into the corpus striatum of rats with lesions of the dopaminergic nigrostriatal neurons. Brain Res 348:283-288.

Herrera-Marschitz M, Stromberg I, Olsson D, Ungerstedt U, Olson L (1984) Adrenal medullary implants in the dopamine-denervated rat striatum. II. Acute behavior as a function of graft amount and location and its modulation by neuroleptics. Brain Res 297:53-61.

Hirsch EC, Duyckaerts C, Javoy-Agid F, Hauw J-J, Agrid Y (1990) Does adrenal graft enhance recovery of dopaminergic neurons in Parkinson's disease? Ann Neurol 27:676-682.

Hsu SM, Rainc L, Fanger H (1981) Usc of avidin-biotin peroxidase complex $(\mathrm{ABC})$ in immunoperoxidase techniques. A comparison between $\mathrm{ABC}$ and unlabeled antibody (PAP) procedures. J Histochem Cytochem 29:577-580.

Hurtig H, Joyce J, Sladek JR Jr, Trojanowski JQ (1989) Post-mortem analysis of adrenal-medulla-to-caudate autograft in a patient with Parkinson's disease. Ann Neurol 25:607-614.

Jaeger CB (1985) Immunocytochemical study of PC- 12 cells grafted to the brain of immature rats. Exp Brain Res 59:615-624.

Jaeger CB (1987) Morphological and immunocytochemical characteristics of PC1 2 cell grafts in rat brain. Ann NY Acad Sci 495:334350.

Jankovick J, Grossman R, Goodman C, Pirozzolo F, Schneider L, Zhu Z, Scardino P, Garber AJ, Jhingran SG, Martin S (1989) Clinical, biochemical, and neuropathologic findings following transplantation of adrenal medulla to caudate nucleus for treatment of Parkinson's disease. Neurology 39:1227-1234.

Jousselin-Hosaja M (1988a) Ultrastructural evidence for the development of adrenal medullary grafts in the brain. Exp Brain Res 73: $637-647$

Jousselin-Hosaja M (1988b) Effects of transplantation on mouse adrenal chromaffin cells. J Endocrinol 116:149,-153.

Kelly PJ, Ahlskog JE, van Heerden JA, Carmichael SW, Stoddard SL, Bell GN (1989) Adrenal medullary autograft transplantation into the striatum of patients with Parkinson's disease. Mayo Clin Proc 64: 282-290.

Kordower JH, Sladek J Jr, Fiandaca MS, Bing G, Gash DM (1988) Tyrosine hydroxylase immunoreactive somata within the primate subfornical organ: species specificity. Brain Res 461:221-229.

Kordower JH, Fiandaca MS, Notter MFD, Hansen JT, Gash DM (1990a) Scientific basis of dopaminergic brain grafting. In: Therapy of Parkinson's disease (Koller WC, Paulson G, eds), pp 443-472. New York: Dekker.

Kordower JH, Fiandaca MS, Notter MFD, Hansen JT, Gash DM (1990b) NGF-like trophic support from peripheral nerve for grafted rhesus adrenal chromaffin cells. J Neurosurg 73:418-428.

Kordower JH, Cochran E, Penn R, Goetz CG (1991) Putative chromaffin cell survival and enhanced host-derived $\mathrm{TH}$-fiber innervation following a functional adrenal medulla autograft for Parkinson's disease. Ann Neurol 29:405-412.

Kordower JH, Felten DL, Gash DM (1992) Dopaminergic transplants for Parkinson's disease. In: Scientific basis for therapy in Parkinson's disease (Olanow CW, Lieberman A, eds), pp 175-224. Lancs, England: Parthenon.

Korsching S, Auburger G, Heumann R, Scott J, Thoenen H (1985) Levels of nerve growth factor and its mRNA in the central nervous system of the rat correlate with cholinergic inncrvation. EMBO J 4:1389-1393.

Krum JM, Rosenstein JM (1987) Patterns of angiogenesis in neural transplant models: I. Autonomic tissue transplants. J Comp Neurol 258:320-334.

Lindvall O, Backlund E-O, Farde L, Sedvall G, Freedman R, Hoffer B, Nobin A, Seiger A, Olson L (1987) Transplantation in Parkinson's disease: two cases of adrenal medullary grafts to the putamen. Ann Neurol 22:457-468.

Lopez-Lozano JJ, Bravo G, Abascal J (1990) A long-term study of Parkinson's patients subjected to autoimplants of perfused adrenal medulla into the caudate nucleus. Transplant Proc 22:2243-2246.

Madrazo I, Drucker-Colin R, Daíz V, Martinez-Mata J, Torres C, Becerrel JJ (1987a) Open microsurgical autorgraft of adrenal medulla to the right caudatc nuclcus in two patients with intractable Parkinson's disease. N Engl J Med 316:831-834.

Madrazo I, Drucker-Colín R, Leon V, Torres C (1987b) Adrenal medulla transplanted to caudate nucleus for treatment of Parkinson's disease report of 10 cases. Surg Forum 38:510-512.

Morihisa JM, Nakamura RK, Freed WJ, Mishkin M, Wyatt RJ (1984) Adrenal medulla grafts survive and exhibit catecholamine-specific fluorescence in the primate brain. Exp Neurol 84:643-653.

Notter MFD, Hansen JT, Okawara S, Gash DM (1989) Rodent and primate adrenal medullary cells in vitro: phenotypic plasticity in response to coculture with $\mathrm{C} 6$ glioma cells or NGF. Exp Brain Res 76: $38-46$.

Olanow CW, Koller W, Goetz CG, Stebbins GT, Cahill DW, Gauger LL, Morantz R, Penn RD, Tanner CM, Klawans HL, Shannon KM, Comella CL, Witt T (1990) Autologous transplantation of adrenal medulla in Parkinson's disease: 18 month results. Arch Neurol 47: 1286-1289.

Olson L, Backlund E-O, Ebendal T, Freedman R, Strömberg I, Hoffer B, Seiger A (1991) Intraputaminal infusion of nerve growth factor to support adrenal medullary autografts in Parkinson's disease: one year follow-up of first clinical trial. Arch Neurol 48:373-381.

Ortega JD, Sagen J, Pappas GD (1992a) Short-term immunosuppression enhances long-term survival of bovine chromaffin cell xenografts in rat CNS. Cell Transplant 1:33-41.

Ortega JD, Sagen J, Pappas GD (1992b) Survival and integration of bovine chromaffin cells transplanted into rat central nervous system without exogenous trophic factors. J Comp Neurol 323:13-24.

Pappas GD, Sagen J (1988) The fine structure of chromaffin cell implants in the pain modulatory regions of the rat periaquaductal gray and spinal cord. In: Progress in brain research, Vol 48, Transplantation into the mammalian CNS (Gash DM, Sladek JR Jr, eds), pp 513-520. Amsterdam: Elsevier.

Paxinos G, Watson C (1986) The rat brain in stereotaxic coordinates, pp 29-34. San Diego: Academic.

Penn RD, Goetz CG, Tanner CM, Klawans HL, Shannon KM, Comella CL, Witt TR (1988) The adrenal medullary transplant operation for Parkinson's disease: clinical observations in 5 patients. Neurosurgery 22:999-1004

Perlow MJ, Freed WJ, Hoffer BJ, Seiger A, Olson L, Wyatt RJ (1979) Brain grafts reduce motor abnormalities produced by destruction of the nigrostriatal dopamine system. Science 204:643-647.

Peterson DI, Lynne-Price M, Small CS (1989) Autopsy findings in a patient who had adrenal to brain transplant for Parkinson's disease. Neurology 39:235-238.

Platt JL, Lindman BJ, Geller RL, Noreen HJ, Swanson JL, Dalmasso AP, Bach FH (1991) The role of natural antibodies in the activation of xenogeneic endothelial cells. Transplantation 52:1037-1043.

Plunkett RJ, Bankiewicz KS, Cummings AC, Miletich RS, Schwartz JP, Oldfield EH (1990) Long-term evaluation of hemiparkinsonian monkeys after adrenal autografting or cavitation alone. $J$ Neurosurg 73:918-926.

Redmond DE Jr, Naftolin F, Collier TJ, Leranth C, Robbins RJ, Sladek 
CD, Roth RJ, Sladek JR Jr (1988) Cryopreservation, culture, and transplantation of human fetal mesencephalic tissue into monkeys. Science 242:768-771.

Rosenstein JM (1987) Adrenal medulla grafts produce blood-brain barrier dysfunction. Brain Res 414:192-196.

Rosenstein JM (1991) Permeability to blood-borne protein and ${ }^{3} \mathrm{HGABA}$ in CNS tissue grafts. I. Intraventricular grafts. J Comp Neurol 305:676-690.

Sagen J, Pappas GD, Perlow MJ (1987) Fine structure of adrenal medullary grafts in the pain modulatory regions of the periaquaductal gray. Exp Brain Res 67:380-390.

Sagen J, Pappas GD, Ortega JD (1990) Host-graft relationships of isolated bovine chromaffin cells in rat periaqueductal gray. J Neurocytol 19:697-707.

Schueler SB, Ortega JD, Sagen J, Kordower JH (1992) Comparison of hovine adrenal medullary grafts and isolated chromaffin cell implants in rats and hemiparkinsonian monkeys. Soc Neurosci Abstr 18:61.

Sedmak DD, Orosz CG (1991) The role of vascular endothelial cells in transplantation. Arch Pathol Lab Med 115:262-265.

Sladek JR Jr, Collier TC, Haber SN, Roth RH, Redmone DE Jr (1986) Survival and growth of fetal catecholamine neurons transplanted into primate brain. Brain Res Bull 17:809-818.

Sladek JR Jr, Redmond DE Jr, Collier TC, Blount JP, Elsworth JD, Taylor JR, Roth RH (1988) Fetal dopamine neural grafts: extended reversal of methylphenyltetrahydropyridine-induced parkinsonism in monkeys. In: Progress in brain research, Vol 78, Transplantation into the mammalian CNS (Gash DM, Sladek JR Jr, eds), pp 497-506. Amsterdam: Elsevier.

Strömberg I, Herrera-Marschitz M, Hultgren L, Ungerstedt U, Olson L (1984) Adrenal medullary implants in the dopamine-denervated rat striatum. I. Acute catecholamine levels in grafts and host caudate as determined by HPLC-electrochemistry and fluorescence histochemical image analysis. Brain Res 297:41-51.

Strömberg I, Herrera-Marschitz M, Ungerstedt U, Ebendal T, Olson L (1985) Chronic implants of chomaffin tissue into the dopaminedenervated striatum: effects of NGF on graft survival, fiber growth and rotational behavior. Exp Brain Res 60:335-349.

Unsicker K, Krisch B, Otten U, Thoenen H (1978) Nerve growth factor-induced fiber outgrowth from isolated rat adrenal chromaffin cells: impairment by glucocorticoids. Proc Natl Acad Sci USA 75: 3498-3502.

Waters C, Itabashi HH, Apuzzo MLJ (1990) Adrenal to caudate transplantation-postmortem study. Movem Disord 5:248-250.

Watson RE Jr, Wiegand SJ, Clough RW, Hoffman GE (1986) Use of cryoprotectant to maintain long-term peptide immunoreactivity and tissue morphology. Peptides 7:155-159.

Wictorin K, Brundin P, Sauer H, Lindvall O, Björklund A (1992) Long distance directed axonal growth from human dopaminergic mesencephalic neuroblasts implanted along the nigrostriatal pathway in 6-hydroxydopamine lesioned adult rats. J Comp Neurol 323:474494.

Yurek D, Sladek JR Jr (1990) Dopamine cell replacement: Parkinson's disease. Annu Rev Neurosci 13:415-440. 